\title{
5 ．小児非侵襲的陽圧人工換気療法の注意点
}

\author{
○鈴木 康之, 中川 聡, 阪井 裕一, 近藤 陽一, 宮坂 勝之
}

（国立小児病院麻酔集中治療科）

非侵襲的陽圧換気療法 (NPPV) は気管内挿 管を必要としない人工呼吸として(1)慢性呼吸不 全患者の人工呼吸, (2)挿管人工呼吸からの離脱 さらに(3)急性呼吸不全や慢性呼吸不全患者の急 性憎悪時において使用され有用性が指摘されて いる。2001年現在, 我が国の在宅人工呼吸患者 の総数は 8000 人を超え, その 70 から $80 \%$ が NPPVであると推定される。そのうち小児患者 は500から600名と推定され、小児在宅 NPPV の実数は不明であるが, 成人同様に今後増加す る可能性があり，その有用性が期待される。そ こで国立小児病院小児 ICUにおいて，挿管人 工呼吸からの離脱目的もしくは呼吸不全治療目 的でNPPVを施行した 9 症例を検討した。年 齢は 7 ケ月から 26 歳で, 巨大縦隔腫湯, 肺炎, ミオパチー，心不全などであった。使用期間は 多くは 1 日から 4 日と短い期間であったが，1 例で20日間, 在宅 NPPVへ移行したネマリン ミオパチーは 3 年 2 ケ間であった。 3 例で離 脱に成功, 6 例が挿管後気管切開自発呼吸もし くは人工呼吸管理となった。離脱失敗例は重度 の脳性麻痷で嚥下障害があり, 気道確保が出来 ない症例であった。重篤な合併症として縦隔気 腫を経験した。

NPPV は低年齢患者ではマスクに耐えられな い, 睡眠時に上気道の解放筋の緊張が低下し,
気道閉塞により有効な換気が難しい症例があ る。急性期の NPPVの試行には必ず，血液ガ スによる酸素化, $\mathrm{CO} 2$, 血圧, 心電図などの充 分なモニターを行い, 患者の綿密な観察が必要 である。憎悪時にいつでも挿管可能な状況で試 行すべきである。NPPV 合併症の鼻根部皮層潰 瘍, 鼻腔口腔内乾燥, 鼻出血, 気胸, 誤嚥, 腹 部膨満に注意が必要である。成長期の小览患者 においては長期使用にともなう，顔面骨形成へ の影響に注意する。NPPVの方が気管切開人工 呼吸よりも会話, 食事, 社会生活において $\mathrm{QOL}$ が向上すると誤解されやすいが，決して そうではなく，小児においては気管切開の方が 安全性の面からも優位にたっている。特に24時 間 NPPV 依存患者においては気管切開管理と すべきと考える。

我々の経験から，人工気道を用いる場合より 手軽で患者に快適な方法だとすることの弊害が 明確である。非侵襲的という名前とは裏腹に, 小児での NPPVには明確な禁忌症例, 状況が ある。意識障害, 多量の喀痰, 嚥下障害, 球麻 瘏などで気道保護反射が阻害されている場合, また介護者に救急蘇生技術がない場合, 十分な 観察体制や能力がない場合は禁忌だと考えるべ きである。 